\title{
Review: Malpighian Tubule, an Essential Organ for Insects
}

\section{Cláudia Aparecida Pacheco ${ }^{1}$, Kaio Cesar Chaboli Alevi ${ }^{2 *}$, Amanda Ravazi and Maria Tercília Vilela de Azeredo Oliveira ${ }^{2}$}

${ }^{1}$ Centro Universitário do Norte Paulista, UNORP, São José do Rio Preto, SP, Brasil

'Laboratório de Biologia Celular, Departamento de Biologia, Instituto de Biociências, Letras e Ciências Exatas, Universidade Estadual Paulista "Júlio de Mesquita Filho", UNESP/IBILCE, São José do Rio Preto, SP, Brasil

\begin{abstract}
We did an overhaul on morphophysiology characteristics, cryptonephric system and secondary specializations in the Malpighian tubules of the class Insecta. This review grouped the most important information about this important organ that has different functions essential for insects.
\end{abstract}

Keywords: Malpighian tubules; Insecta class; Excretory system; Cocoon

\section{Malpighian Tubules: Morphophysiology Characteristics}

The Insecta class comprises approximately 1.000 .000 species distributed in 32 orders [1]. The excretory system in insects and terrestrial arthropods consists of structures called Malpighian tubules. This organ, like the posterior intestine forms the primary system in insects for ionic, osmotic and excretory regulation by which excretion products and toxic compounds are transported. The final phase of excretion occurs in the rectum, with ions and water is reabsorbed at this location. Thus, the large intestine which is the final composition of urine is formed. Substances removed from the urine as water and ions are transferred through intimate connections between the posterior intestine and tubules. Thus, these organs are extremely important in insects because maintains constant internal environment through the elimination or segregation of unnecessary substances present in the hemolymph, and the retention or reabsorption of useful substances to the body [2].

The main function of the Malpighian tubules of insects is the excretion of nitrogenous products and other remains of metabolites. The Malpighian tubules also secrete fluids within the posterior intestine where they are reabsorbed and certain substances are transported into the hemolymph [3].

The Malpighian tubules may be present in variable numbers in different orders of the class Insecta, for example, to Odonata this number varies between 50 and 60 tubules in Hemiptera from 1 to 4, in Lepidoptera that number is 6, in Hymenoptera ranges from 12 to 150, in Orthoptera from 2 to 200, while the Diptera is only 4 tubules. In many species, the tubules are separated into morphologically different regions and each region is homogeneous for one cell type [4].

The Malpighian tubules works as follows: potassium is actively secreted into the lumen of the tubules and water follows passively due to osmotic forces, resulting in the formation of an abundant amount of potassium-rich liquid. This fluid is isotonic relative to hemolymph, but has a quite different composition that differs in surprising ways with the mammalian kidney in which the initial urinary fluid is an ultrafiltrate of blood plasma.

Within the Malpighian tubule fluid is modified through processes of secretion and resorption, then there is passage of fluid into the posterior intestine where most of the solutes and water are reabsorbed, occurring the precipitation of uric acid (part the fluid in the form of water-soluble potassium urate). This facilitates subsequent removal of water, because the precipitated uric acid does not contribute to the osmotic activity of the rectal contents. Finally, the remaining content is expelled into the rectum feces mixed with urine [5].
The secretion rates of fluid and ions by Malpighian tubules of insects are controlled by peptides. The tubular secretion rate is controlled by the interaction of two or more factors that are produced in the haemolymph. These interactions can be classified as synergistic factors affecting as diuretics, so that fluid secretion is stimulated. In cooperative interaction, the factors of diuretics may act in cooperation, through their full effects on transportation routes of cations and anions. In antagonist by a factor acts as a stimulator and the other as an inhibitor of [6].

\section{Cryptonephric System}

The Malpighian tubules are inserted tubular organs in the area between the medium intestine and posterior intestine, which often are free and loose in the body cavity, and in some insects, as already mentioned, the distal end of these tubules found in contact with the wall of the rectum through the perinephric membrane, an arrangement known as 'cryptonephric complex'. This system facilitates the reabsorption of water and, therefore, is more highly developed in insects that feed on dry substances or live in a relatively dry environment and therefore need to retain water $[4,7]$.

Notably in beetles that feed on dry substance, a special arrangement associated with an extraordinary ability to draw water from excrement occurs. In these insects, to a tubular blind end is in intimate association with the rectum, the entire structure is surrounded by a peripheral membrane. The space formed by the membrane is filled with a fluid which surrounds the Malpighian tubule and rectal epithelia, but is separated from the hemolymph.

In Tenebrio molitor (Coleoptera) are found four morphologically different regions. These insects have a special arrangement and an extraordinary ability to draw water from excrement, ending the Malpighian tubule blindly and in association with the rectum is surrounded by a membrane perirectal [8].

*Corresponding author: Kaio Cesar Chaboli Alevi, Instituto de Biociências Letras e Ciências Exatas, IBILCE - UNESP. Rua Cristovão Colombo, Brasil, Tel: (17)32212380 Ramal: 2378; E-mail: kaiochaboli@hotmail.com

Received February 06, 2014; Accepted February 21, 2014; Published February 24, 2014

Citation: Pacheco CA, Alevi KCC, Ravazi A, de Azeredo Oliveira MTV (2014) Review: Malpighian Tubule, an Essential Organ for Insects. Entomol Ornithol Herpetol 3: 122. doi:10.4172/2161-0983.1000122

Copyright: (c) 2014 Pacheco CA, et al. This is an open-access article distributed under the terms of the Creative Commons Attribution License, which permits unrestricted use, distribution, and reproduction in any medium, provided the original author and source are credited. 
Another example is the Palpares annulatus larvae (Neuroptera, Myrmeleontidae) living in arid and semi-arid savannah of the Kalahari in southern Africa, and are exposed to long periods of food deprivation and short periods of food abundance. At this stage, the larvae of insects of this family are voracious predators and form of digestion is very specialized. The extra-intestinal digestion, that is, the digestive enzymes are injected into the prey thus dissolving the soft tissues. The liquid is then sucked through the narrow channels between the jaws and maxillae. The ingested food is trapped in a structure shaped bag in a blind bottom, slowly being absorbed by highly specialized internal epithelium. This organ has a yellowish tint in the front portion becomes brown in the posterior portion to the presence of meconium formed by food residues. This portion of the alimentary canal is discontinuous with the intestine and other structures [9].

The intestine itself is a tube of uniform diameter and leave the anterior portion of the Malpighian tubules eight, six of which are cryptonephrid, that is, connect again with the rear portion forming the bowel loops and the other two are free. This point of attachment of the six Malpighian tubules marks the beginning of the rectal pouch, which subsequently narrows to form the rectum. The digestive tract in larval stage is incomplete, because the anus is imperforate.

This arrangement of the Malpighian tubules known as cryptonephric system is present in most of the larvae of Lepidoptera, Neuroptera, Diptera, Symphita and adults of Coleoptera, however, only a few Coleoptera and Diptera have been well documented [4,7].

Thus, cryptonephric system in insects is known to be involved in the reabsorption of water through the rectal area while the majority of larvae of Lepidoptera, which have a diet rich in succulent leaves, this system appears to be related to remove excess ions from the hemolymph. Green, in 1980, [10] states that in light Arachnocampa (Diptera), the system may be primarily a local storage nutrients absorbed from the rectum and used by certain segments of the Malpighian tubules.

Based on structural and physiological system cryptonephric Tenebrio molitor (flour beetles) investigations, it has been proposed a mechanism by which the complex rectal should function in absorption of water [11].

\section{Secondary Specializations in Malpighian Tubules}

In most insects the Malpighian tubules are all the same, although in some as Gryllotalpa (Orthoptera), there are three types of tubules that are completely different based on the total composition. There are white, yellow and embryonic tubules, each seeming to have a different function. However, other roles for each type of tubule was not conclusively demonstrated [12].

The existence of multiple segments, each with a different along the Malpighian tubules of insects structure has been established in numerous species: Vanessa urticae (Lepidoptera), Jassidae sp. (Homoptera), Mantis religiosa (Dictyoptera), Locusta migratoria (Orthoptera), Macrosteles (Homoptera), Gryllus domesticus (Orthoptera), Rhodnius prolixus (Hemiptera), Drosophila melanogaster (Diptera), Cenocorixa bifida (Hemiptera) (Jarial e Scudder, 1970), Periplaneta americana (Dictyoptera), Arachnocampa luminosa (Diptera), Blatella germanica (Blattaria) e Tenebrio molitor (Coleptera). The number of segments, however, is not the same in all species [13].

The epithelium of the Malpighian tubule firefly New Zealand, Arachnocampa luminosa, there are four distinct regions, each made up of different cell types: cells of the proximal region (Part I), the large and granulosa cells (Part II), small cells of the distal narrow region (Part III) and the distal cells of the organ of luminescent light (Part IV) [14].

In Malpighian tubules of Solenopsis saevissima (Hymenoptera), three segments were distinguished: proximal, middle and distal, and this distinction is based on the shape and structure of the epithelial cells lining the different segments of the tubules [15].

Aedes aegypti has five Malpighian tubules formed by large and small cells, called, respectively, the main cells (or primary) and stellate cells. Morphological differences involving Malpighian tubules of males and females were also reported, although the diameter of the tubular female twice that of males, as well as the main cells and their nuclei is also higher [16].

In other species, Aedes taeniorhynchus, the Malpighian tubules do not exhibit distinct regions, although an arrangement of two types of cells is observed. One type of cell is called primary cells which comprise the majority of tubule cells and the second cell type is called a star. It is suspected that the primary cells are the site of production of primary urine, as has been proposed that stellate cells may be involved in the reabsorption of $\mathrm{Na}+$ from the primary urine [17].

Larvae of other Diptera, Ephydra hians, are found in hypersaline lakes of northwestern North America [18]. According to this author physiological specializations must occur for these larvae live in an unusual environment like this. Ephydra hians larvae are capable of maintaining osmoregulation in the hemolymph with an osmotic concentration ten times higher than the blood. They possess a pair of Malpighian tubules containing large amounts of a white substance, compared with the other pair that does not contain the substance. It was observed that these white granules dissolved in uric acid release gas bubbles, suggesting the possibility that the modified tubular stock must carbonate [19].

According to Berridge and Oschman, in 1969 [17], the fly sucking Calliphora erythrocephala, as well as Aedes is a heterogeneous arrangement in which the Malpighian tubules have primary and stellate cells, which are responsible for the secretion of primary urine containing $\mathrm{Na}^{+}, \mathrm{K}^{+}$, and $\mathrm{Cl}^{-}$into the lumen of the Malpighian tubules. As already mentioned, these authors proposed that stellate cells are the sites of $\mathrm{Na}+$ reabsorption from the primary urine.

Secondary specializations are also observed in the Malpighian tubules of two superfamilies of the order Hemiptera (Cercopoidea and Membracoidea), where the distal portions of the Malpighian tubules are involved in the production of proteins, while the proximal portions which are more inflated, are responsible for producing proteins and glycosaminoglycans [20-24]. These various substances have a role in the composition of the cocoon, and in adults the morphological difference between the secretory segments disappears and secretory activity apparently ceases [25].

Special regions of the Malpighian tubules of certain coleopteran larvae, and also produce silk Neuroptera [26]. Thus, the silk production in insects is not unique to labial gland, glands and other tissues may also produce this material [27].

The Malpighian tubules are almost exclusively engaged in secretory mechanisms. Products most commonly found in the lumen of these organs are uric acid, ammonia, salts, riboflavins, pterines and ions [28]. However, a few exceptions are reported in the preparation of special secretions such as glycoproteins and glycosaminoglycans.

The Malpighian tubules of larvae of certain chrysomelids prepare 
Citation: Pacheco CA, Alevi KCC, Ravazi A, de Azeredo Oliveira MTV (2014) Review: Malpighian Tubule, an Essential Organ for Insects. Entomol Ornithol Herpetol 3: 122. doi:10.4172/2161-0983.1000122

Page 3 of 3

a sticky substance that seems to help procreation in some species [29] and are used to cover the eggs chambers in other species [30]. Nymphs Cercopidae produce a glycoprotein secretion, possibly related to silk production [31].

Thus, this review has grouped the most important information concerning this important organ that has different functions essential for insects.

\section{References}

1. Virgilio M, Backeljau T, Nevado B, De Meyer M (2010) Comparative performances of DNA barcoding across insect orders. BMC Bioinformatics 11: 206

2. Pannabecker T (1995) Physiology of the Malpighian Tubule. Ann Rev Entom 40: 493-510.

3. Maddrell SHP (1971) The mechanism of insect excretory systems. Adv Ins Phys 8: 199-331.

4. Bradley TJ, Stuart AM, Satir P (1982) The ultrastructure of the larval malpighian tubules of a saline-water mosquito. Tissue Cell 14: 759-773.

5. Saini RS (1964) Histology and physiology of the cryptonephridial systems of insects. Trans Ent Society of London 116: 347-392.

6. O'Donnell MJ, Spring JH (2000) Modes of control of insect Malpighian tubules: synergism, antagonism, cooperation and autonomous regulation. J Insect Physiol 46: 107-117.

7. Chapman RF (1998) The insects: structure and function. Fourth Ed. Cambridge University Press, Cambridge.

8. Meyran JC (1982) Comparative study of the segmental specializations in the Malpighian tubules of Blatella germanica (L.) (Dictyoptera: Blatellidae) and Tenebrio molitor (L.) (Coleoptera: Tenebrionidae). J Ins Morph Emb 11: 79-98.

9. Van Zyl A, Van Der Linde TC (2000) Anatomy and histology of the alimentary canals of the Palpares annulatus Stitz (Neuroptera, Myrmeleontidae) with reference to their feeding physiology. Africa Entomol 8: 179-188.

10. Green LF (1980) Cryptonephric malpighian tubule system in a dipteran larva, the New Zealand glow-worm, Arachnocampa luminosa (Diptera: Mycetophilidae) a structural study. Tissue Cell 12: 141-151.

11. Grimstone AV, Mullinger AM, Ramsay JA (1968) Further studies on the recta complex of the mealworm, Tenebrio molitor L. (Coleoptera, Tenebrionidae). Phil. Trans. R. Soc. Ser 253: 343-382.

12. Ryerse JS (1979) Developmental changes in Malpighian tubule cell structure Tissue Cell 11: 533-551.

13. Meyran JC (1982) Segmental variations of intercellular junctions in insect Malpighian tubules: a comparative study of two species. J Ultrastruct Res 79: 31-46.

14. Green LF (1979) Regional specialization in the Malpighian tubules of the New Zealand glow-worm Arachnocampa luminosa (Diptera: mycetophilidae). The structure and function of type I and II cells. Tissue Cell 11: 673-703.

15. Arab A, Caetano FH (2002) Segmental specializations in the Malpighian tubules of the fire ant Solenopsis saevissima Forel 1904 (Myrmicinae): an electron microscopical study. Arthropod Struct Dev 30: 281-292.

16. de Sousa RC, Bicudo HE (2000) Morphometric changes associated with sex and development in the Malpighian tubules of Aedes aegypti. Cytobios 102: 173-186.

Citation: Pacheco CA, Alevi KCC, Ravazi A, de Azeredo Oliveira MTV (2014) Review: Malpighian Tubule, an Essential Organ for Insects. Entomol Ornithol Herpetol 3: 122. doi:10.4172/2161-0983.1000122
17. Berridge MJ, Oschman JL (1969) A structural basis for fluid secretion by malpighian tubules. Tissue Cell 1: 247-272.

18. Herbest DB (1986) Comparative studies of the population ecology and life history patterns of an alkaline salt lake insect: Ephydra (Hydropyrus) hians (Diptera: Ephydridae). PhD Dissertation Oregon State University. 206.

19. Herbest DB, Bradley A (1989) Malphigian tubules lime gland in an insect inhabiting alkaline salt lakes. J Exp Biol 145: 63-78.

20. Marshall AT (1964) Spidle-production and tube-building by cercopoid nymphs (Homoptera). The cytology of the Malpighian tubules of spittle-bug nymphs. J Mic Sc 105: 257-262.

21. Marshall AT (1964) Spidle-production and tube-building by cercopoid nymphs (Homoptera). The citology and function of the granule zone of the Malpighian tubules of tube-building nymphs. J Mic Sc 105: 415-422.

22. Marshall AT (1964) Spindle-production and tube-building by cercopoid nymphs (Homoptera). The cytology and function of the fibril zone of the Malpighian tubules of tube-building nymphs. J Mic Sc 106: 37-44.

23. Marshall AT (1973) Protein synthesis and secretion by the Malpighian tubules of cercopoid larvae (Homoptera). J Ins Phys 19: 2317-2326.

24. Marshall AT (1974) Golgi body function and mucocomplex secretion in the Malpighian tubules of cercopoid larvae (insecta: Homoptera). J Ultrastruct Res 47: 95-105.

25. Rakitov RA (1999) Secretory products of the Malpighian tubules of Cicadellidae (Hemiptera, Membracoidea): an ultrastructural study. Exp J Ins Morp Emb 28 : 179-193.

26. Wigglesworth VB (1972) The principles of insect physiology. Chapman and Hall, London.

27. Rudall KM, Kenchington W (1971) Arthropod silks: the problem of fibrous proteins in animal tissues. An Rev Entomol 16: 73-96.

28. Wigglesworth VB (1965) The principles of insect physiology. (6thedn). Methuen and Co Ltd., London.

29. Pacheco CA, Alevi KCC, Silva TL, Azeredo-Oliveira MTV, Ceron CR, et al. (2014) Nucleolar activity during larval development of Myrmeleon uniformis Navas, 1920 (Neuroptera, Myrmeleontidae). Gen Mol Res, in press.

30. Heymons R, Luchmann M (1933) Die vasa Malpighi von Gallerucella viburn Payk (Coleoptera), Zoology Anz 102: 78-86.

31. Pesson P (1955) Secretion d'une mucoproteine par les tubes de Malpigh dês larves de Cercopides. Son role dans la formation de l'abri spumox. Boll. Laboratorie Zool. Gen. Agr 33: 341-349.

Submit your next manuscript and get advantages of OMICS Group submissions

Unique features:

- User friendly/feasible website-translation of your paper to 50 world's leading languages

Audio Version of published paper

Digital articles to share and explore

Special features:

300 Open Access Journals

25,000 editorial team

21 days rapid review process

Quality and quick editorial, review and publication processing

- Indexing at PubMed (partial), Scopus, EBSCO, Index Copernicus and Google Scholar etc

- Sharing Option: Social Networking Enabled

- Authors, Reviewers and Editors rewarded with online Scientific Credits

- Better discount for your subsequent articles

Submit your manuscript at: www.omicsonline.org/submission/ 